Family Medicine and Community Health

\section{One size does not fit all: adapt and localise for effective, proportionate and equitable responses to COVID-19 in Africa}

To cite: MacGregor $\mathrm{H}$, Leach $\mathrm{M}$, Tshangela A, et al. One size does not fit all: adapt and localise for effective, proportionate and equitable responses to COVID-19 in Africa. Fam Med Com Health 2021;9:e000709. doi:10.1136/ fmch-2020-000709

Received 25 August 2020 Revised 11 February 2021 Accepted 22 February 2021
Check for updates

(C) Author(s) (or their employer(s)) 2021. Re-use permitted under CC BY. Published by BMJ.

${ }^{1}$ Institute of Development Studies, Brighton, UK ${ }^{2}$ Africa Centres for Disease Control and Prevention, African Union, Addis Ababa, Ethiopia ${ }^{3}$ Department of Global Health and Development, London

School of Hygiene \& Tropical

Medicine, London, UK

${ }^{4}$ Anthrologica, Oxford, UK

Correspondence to Dr Hayley MacGregor; h.macgregor@ids.ac.uk

\section{INTRODUCTION}

The heterogeneous epidemiological picture for COVID-19 in Africa continues to generate debate. Modelling projections raise speculation about the phases and trends of SARS-CoV-2 outbreaks across the continent and how these differ from outbreaks elsewhere. ${ }^{1-4}$ Continental efforts drew praise in the first wave of COVID-19, and success has been linked to African experience of epidemics and to decisive leadership. ${ }^{4}$ Yet the tendency at the outset of the pandemic with initial responses to the threat of COVID-19 was for African governments to look to standard models emphasising central control, following the WHO and partly mirroring the stringent restrictions as already deployed in Asia and Europe. The negative effects of 'lockdowns' and a vertical, disease-specific 'health security' response on livelihoods, food security and healthcare for other conditions have threatened to overshadow the direct suffering and even mortality engendered by COVID-19 alone. ${ }^{5}$ These effects have been evident also in high-income countries but manifested rapidly and intensely in Africa. This scenario highlights the problems of generic approaches to response given very different settings in which a pandemic unfolds, suggesting that further attention should have been paid by decision makers to significant adaptation to African realities from the start. The continent is also hugely diverse in health system and social protection capacities, demographics and population density, underscoring an argument for adaptation and contextualised responses across African settings. Moreover, since the initial imposition of extensive curtailment, political and economic pressures necessitated an easing of 'lockdowns' as 2020 progressed. More limited measures are evident in situations where cases of community transmission of SARS-CoV-2 and deaths have risen as some countries face a second wave. ${ }^{6}$ All of these factors, alongside the paucity of resources, lack of definitive pharmacological treatments and likely delays in deployment of vaccines on the continent, have further intensified the need for context-appropriate public health and social measures, tailored to ensure proportionality of responses as differing scenarios unfold.

We contend that a critical part of adaptation and proportionality is a localisation of response that builds on people's own inventiveness and the knowledge and experience of local organisations. Drawing on knowledge exchange webinars run collaboratively between the Africa Centres for Disease Control and the Social Science in Humanitarian Action Platform in 2020, we consider positive examples of adaption that have emerged. We present a preliminary typology of important domains for localisation of public health and social measures, with a focus on interventions to protect people who are vulnerable-socially, economically, politically and also biologically. We call for acknowledgement of the importance of local-level responses and the need to support these and for the establishment of fora to share learning about adaptation and effective models. Streamlined funding mechanisms that allow for rapid flow of resources to support initiatives 'from below' ${ }^{, 7}$ also need to be strengthened. 
Table 1 Typology of Adaptive Responses with selected examples

Domain Example of intervention

Mitigating hardship

Livelihoods in the informal economy

Burkina Faso announced support for informal sector workers, as did Egypt and Tunisia. In Namibia, South Africa and Zimbabwe one-off or temporary cash grants have been provided to vulnerable people. Coverage depends on the strength of social protection systems and on access to mobile phones (for cash transfers), ID cards or inclusion in state databases. https:// www.wiego.org/government-responses-covid-19-crisis

Food insecurity Community Action Networks investigate the most appropriate ways to provide food relief for the hungry in Cape Town, South Africa. https://theconversation.com/local-networks-can-helppeople-in-distress-south-africas-covid-19-response-needs-them-138219

Food markets

Urban municipal government in Bo, Sierra Leone, works with local researchers to identify hygiene and physical distancing measures in a busy open market to enable it to stay open safely. https://africanarguments.org/2020/03/30/preparing-for-covid-19-in-africa/.

\section{Care of the ill}

Home care for COVID-19

Amref has partnered with governments to provide training on the safe provision and support of homecare for COVID-19 to community health workers via the Leap app, which works on simple mobile phones. https://newsroom.amref.org/blog/2020/08/building-health-worker-capacity-onhome-based-care-and-isolation-using-digital-learning-in-kenya/

\section{Protecting the medically vulnerable}

Shielding the clinically vulnerable

Maintaining essential healthcare

\section{Preventing transmission}

Local information

Dialogue and trust

Burials

Isolation of those who are positive

Screening, testing and contact tracing

Hygiene provision
Shielding is informally underway in Ethiopia, where community society groups and nongovernmental organisations provide food, infection prevention and basic economic support to the shielded. https://gh.bmj.com/content/5/7/e003204.info

The International Community of Women Living with HIV West Africa has partnered with healthcare facilities to recruit a cadre of 'community pharmacists' to home deliver treatments for HIV and other conditions in Nigeria and Côte d'Ivoire. https://www.unaids.org/en/resources/ presscentre/featurestories/2020/july/20200714_arv-cotedivoire-nigeria

An existing network of residents has organised monitoring and 'situation tracking' of COVID-19 in informal settlements in Nairobi in order to liaise with the city government about service provision and the local situation, with assistance of community health volunteers. https://www. muungano.net/muunganos-covid-19-response

In Kivu, DRC, members of the Amani Institute, a sociocultural movement, have worked with youth volunteers who visit public spaces and homes of internally displaced persons to share information about COVID-19 prevention. https://amani-institute.org/2020/05/04/coronavirus-ina-context-of-conflicts-and-humanitarian-crisis-in-eastern-drcongo/

Traditional leaders in South Africa's Eastern Cape have reintroduced ukuqhusheka or 'secret burials', a historic funerary practice with cultural significance that limits the number of people who attend bodies and burials. https://www.bbc.co.uk/news/world-africa-52571862

Slum and Shack Dwellers International Kenya has provided input to the Department of Health's guidelines for Isolation Centres, taking account of conditions in informal settlements. https:// www.muungano.net/browseblogs/2020/6/11/covid-19-muungano-alliance-contributes-togovernment-guidelines-on-isolation-centers

In South Africa, cadres of community healthcare workers were deployed early for communitylevel screening and referral for testing, using skills gained in combating HIV and tuberculosis. https://www.ft.com/content/98d0d7c6-9bfb-4a64-bcab-19e0854a3b4d

Handwashing stations have been installed in places with limited water infrastructure, for example, informal settlements in Kenya and Rwanda. In Sudan, community committees made and distributed their own sanitisers. https://blogs.worldbank.org/nasikiliza/innovations-timecovid-19-rising-pandemics-challenges-africas-informal-settlements
The politics of easing restrictions: balancing public health action against the impacts of measures

The current dilemmas faced by African governmentsas elsewhere-bring to the fore the reality that epidemic preparedness and response are not neutral, scientific processes but deeply political and social as well. Decision makers are inevitably influenced by politics and economics, in addition to scientific data. Indeed, amidst 
the great scientific and societal uncertainty that an emergent pathogen generates, it may be politically easier to pursue standardised routes of preparedness and response, which prioritise containment through top-down, diseasespecific, state-led interventions. ${ }^{8}$ The political responses across African countries have been complex and diverse and reflect national and geopolitical tensions, as elsewhere. Definitive 'lockdowns' can have political meaning and even gain for governments that wish to be seen to act swiftly and take strong control in a crisis. In the extreme, some have been accused of using the pandemic to legitimate excessively authoritarian responses. ${ }^{9}$ Stringent measures might have delayed outbreaks initially or even contained them in some contexts, but the secondary impacts on economies, livelihoods and health have necessitated a weighing up of the relative effects of an outbreak surge against those of the restrictions. These decisions have become even more difficult as several African countries have experienced a second wave of COVID-19 that has proven to be more deadly than the first and as mutations have increased transmissibility of the virus.

In May, Africa CDC issued guidance on the easing of restrictions while warning also that it was likely Africa would yet become a frontier of the pandemic ${ }^{10}$ with community transmission increasing in some countries. These apparently paradoxical messages highlighted that such easing, too, involved consideration of political and economic factors as well as epidemiological ones-the lifting of lockdowns in Africa became necessary to save lives, economies and livelihoods, as was made explicit in the launch of an African Union campaign 'Africa against COVID-19' in mid-August 2020. Social and economic vulnerability on the continent is exacerbated by high reliance on informal economic activity and on local markets for food, a lack of social protection safety nets ${ }^{11}$ and living conditions in densely populated and poorly serviced urban settlements where physical distancing, isolation and hygiene measures are difficult to achieve. ${ }^{12}$ Sustaining livelihoods is ultimately linked to saving lives but easing restrictions also saves lives more directly. In addition to food insecurity causing malnutrition, the prioritisation of responses to COVID-19 has disrupted essential health services, such as for immunisation and care of other prevalent diseases. Contributing factors include issues of supply (disruption of flows of drugs and equipment, illness or redeployment of staff) and access (lack of transport to reach services and fear of breaching restrictions). ${ }^{13}$

\section{One size does not fit all: adaptation and localisation of responses is key}

These realities point to a strong argument for responses that are adapted and proportionate to local contexts and epidemiology. With the easing of more extreme containment measures, national-level interventions for reducing community transmission that minimise impact on broader aspects of socioeconomic well-being have become more important. At local levels, it has become necessary to adapt physical distancing, hand washing, isolation and community-based care to prevalent realities such as multi-occupancy in crowded dwellings or the absence of running water.

As restrictions ease for general publics, a further key question is how to protect those particularly vulnerable to COVID-19. Strategies may include developing practicable means for 'shielding' the clinically vulnerable ${ }^{14}$ in multigenerational households, medication delivery for the chronically ill to reduce exposure or food and cash relief for those who are suffering economically.

In this respect, initiatives developed at community level, led by a range of local actors, are likely to be a vital aspect of localisation and adaptation of standardised outbreak response guidelines. The 2013-2016 West Africa Ebola outbreak provided clear evidence that local-level action can be significant in turning epidemics around. For example, citizens applied insights and past experience of disease control to protect themselves ${ }^{15}$ and to arrange safe burials and morally acceptable care of kin. ${ }^{16}$ Harnessing mobilisation, knowledge and inventiveness 'on the ground' and hearing from local people about their priorities, or concerns about other prevalent health and livelihood issues, is key to a proportionate and effective response that people understand and trust. Local organisations can document conditions, such as inequalities in availability of services, and provide access to a spectrum of information that can be vital for moving forward effectively. This can include epidemiologically relevant reports, given the lack of testing or recording of deaths in some settings. Localisation can also enable a response that is attentive to social differences and vulnerabilities.

\section{A typology of emerging locally adaptive responses}

At this juncture, it is critical to share learning widely. To this end, we have distilled emerging domains for interventions, drawn from our knowledge and presented in a preliminary typology of adapted responses with localised examples (table 1). This table is not exhaustive but envisaged as an illustrative starter on a range of adapted alternatives, so that these can be documented and disseminated.

\section{Supporting interconnections between state-led responses and} mobilisation 'on the ground'

A range of actors have been involved in localised interventions, including community-based and faith-based and other non-governmental organisations and the private sector, sometimes in partnership with central government, local authorities or international agencies. Other initiatives involve networks and federations, such as of informal settlement residents, or civil society groups. Furthermore, local organisation by those with informal authority can help in a crisis like COVID-19, as indeed occurred with Ebola in West Africa. ${ }^{16}$ Limitations in government capacities highlight the importance of coordinated activity between state responses and those 'from below', and interconnections and synergies between local experience and action, and government-led public health responses. The nature of existing governance structures 
can help determine which actors are best placed to coordinate efforts. Community-based actors with recognised local authority can act as key interlocutors and improve dialogue and trust. ${ }^{12}$

In arguing for adaptation and localisation, we are not proposing that the lion's share of responsibility for preventing community transmission, mitigating socioeconomic impacts or protecting the vulnerable should fall on 'communities' or that responsibility to reduce infection risk should be construed as located with individuals alone. When extensive state-enforced restrictions are eased, it is easy for governments to resort to transferring responsibility for preventing infections to individuals or local leaders. This is especially problematic in contexts characterised by structural violence and where people's living conditions make public health measures challenging to meet. It can lead to the blaming of groups and individuals who are marginalised, further intensifying inequalities that COVID-19 has laid bare. National, municipal and local authorities have important roles to play in partnering with community and grassroots groups to support and enable their efforts. Locallevel action can play a further role in holding the state to account, if the political environment is favourable.

\section{CONCLUSION}

Response plans for epidemics that privilege top-down action have been the norm, and governments have frequently echoed restrictive measures for COVID-19 as implemented in other global regions. For African countries, mounting evidence of deleterious effects of stringent approaches has led to growing acknowledgement of their limitations, and of the necessity for a diversity of responses, given also epidemiological heterogeneity. Various responses are emerging as decision makers in different countries adapt guidelines and pursue particular strategies, according to their social, economic and political contexts, as well as their histories and past disease experiences. Greater appreciation by scientists and policymakers of this diversity and its contextual shaping by factors that extend beyond epidemiology and public health need alone, is badly needed. We argue that it is also necessary to pay serious attention to initiatives that adapt measures at the local level, led by a range of actors and even emerging 'from below'. This can assist in attuning interventions to different contextual realities and in ensuring that they are proportionate, attentive to vulnerabilities and social inequalities and socially just. We have shared some emergent positive examples that could be built on but this requires political will. These initiatives have been at the margins and urgently need to be brought in more centrally and given greater recognition and resourcing, both from national and international sources. Improving interconnections between responses 'from above' and 'from below' will be critical in moving forward.

Contributors The commentary was drafted by HM, and HM and ML did the initial conceptualisation. Further conceptual and written input was given by AT of the Africa Centres for Disease Control and Prevention. The members of the Social
Science in Humanitarian Action Platform executive gave input into the argument and commented on text (TAH, SL, EN, MP, SRL, HR, MS-S, OT and AW) and text for examples in the table (AW, EN, TAH, SRL and OT). Contribution from this group has been equal, and they are listed after HM and ML in alphabetical order.

Funding This study was funded by Wellcome Trust and DFID 219169/Z/19/Z. Competing interests None declared.

Patient consent for publication Not required.

Provenance and peer review Not commissioned; externally peer reviewed.

Open access This is an open access article distributed in accordance with the Creative Commons Attribution 4.0 Unported (CC BY 4.0) license, which permits others to copy, redistribute, remix, transform and build upon this work for any purpose, provided the original work is properly cited, a link to the licence is given, and indication of whether changes were made. See: https://creativecommons.org/ licenses/by/4.0/.

\section{ORCID iDs}

Hayley MacGregor http://orcid.org/0000-0002-9392-9331

Tabitha A Hrynick http://orcid.org/0000-0001-9571-5874

Shelley Lees http://orcid.org/0000-0003-0062-7930

Santiago Ripoll Lorenzo http://orcid.org/0000-0002-1735-0432

\section{REFERENCES}

1 Twahirwa Rwema JO, Diouf D, Phaswana-Mafuya N, et al. COVID-19 across Africa: epidemiologic heterogeneity and necessity of Contextually relevant transmission models and intervention strategies. Ann Intern Med 2020;173:752-3.

2 Mbow M, Lell B, Jochems SP, et al. COVID-19 in Africa: dampening the storm? Science 2020;369:624-6.

3 Nordling L. The pandemic appears to have spared Africa so far. scientists are struggling to explain why, 2020. Available: https:// www.sciencemag.org/news/2020/08/pandemic-appears-havespared-africa-so-far-scientists-are-struggling-explain-why?utm _ source=Nature+Briefing\&utm_campaign=b6db6ce366-briefingdy-20200813\&utm_medium=email\&utm_term $=0$ _c9dfd39373b6db6ce366-45179894 [Accessed Aug 2020].

4 Maeda JM, Nkengasong JN. The puzzle of the COVID-19 pandemic in Africa. Science 2021;371:27-8.

5 Tony Blair Institute for global change. COVID-19 in Africa - and Africa beyond COVID-19, 2020. Available: https://institute.global/sites/ default/files/inline-files/Tony\%20Blair\%20Institute $\% 2 \mathrm{C} \% 20 \mathrm{Covid}$ $19 \% 20$ and $\% 20$ Africa\%20and\%20Africa\%20Beyond\%20Covid-19\% 2C\%20May\%202020v2.pdf

6 An African plan to control COVID-19 is urgently needed. Lancet 2020;396:1777.

7 Leach M, MacGregor H. Pandemic preparedness: who is being prepared for what and by whom? 2019;29 https://www.ids.ac.uk/ opinions/pandemic-preparedness-who-is-being-prepared-for-whatand-by-whom/

8 MacGregor H, Ripoll S, Leach M. Disease Outbreaks: Navigating uncertainties in Preparedness and Response. In: Scoones I, Stirling A, eds. The politics of uncertainty. Abingdon: Routledge, 2020.

9 Smith J, Cheeseman N. itarians are exploiting the coronavirus. Democracies must not follow suit. Foreign Policy 2020;28 https:// foreignpolicy.com/2020/04/28/authoritarians-exploiting-coronavirusundermine-civil-liberties-democracies/

10 Massinga Loembé M, Tshangela A, Salyer SJ, et al. COVID-19 in Africa: the spread and response. Nat Med 2020;26:999-1003.

11 Barasa E, Mothupi MC, Guleid F. Health and socio-economic impacts of physical distancing for COVID-19 in Africa. KEMRI-Wellcome Trust Research Programme and African Academy of Sciences, 2020.

12 Wilkinson A, Ali $\mathrm{H}$, Bedford J, et al. Local response in health emergencies: key considerations for addressing the COVID-19 pandemic in informal urban settlements. Environ Urban 2020;32:503-22.

13 Chi Y-L, Regan L, Nemzoff C. Beyond COVID-19: a whole of health look at impacts during the pandemic response. policy paper 177 . Center for Global Development 2020 https://www.cgdev.org/ publication/beyond-covid-19-whole-health-look-impacts-duringpandemic-response

14 Dahab M, van Zandvoort K, Flasche S. Conflict and health 2020;14.

15 Richards P. Ebola: how a people's science helped end an epidemic. London: Zed Books, 2016.

16 Parker M, Hanson TM, Vandi A, et al. Ebola and public authority: saving Loved ones in Sierra Leone. Med Anthropol 2019;38:440-54. 